\title{
Women, Poverty and Trafficking: A Contextual Exposition of the Nigerian Situation
}

\author{
Fayomi O. O. \\ Department of International Relations and Strategic Studies \\ Covenant University Ota, Ogun State Nigeria
}

\begin{abstract}
Human trafficking is beginning to attract global attention as a result of its detrimental consequences for development. This is especially so in the African context where the incidence of human trafficking - especially women's trafficking has been increasingly attributed to the incidence of poverty worsened by the neo-imperialist capitalist pattern of development culture which maximizes individual profiteering and wellbeing above communal well being. Formal and informal discourses in Social Sciences have tended to link the incidence of women trafficking with the rising incidence of poverty in the 21 st Century African State.

This paper questions the veracity in the proposed systemic connections between poverty and trafficking especially with regards to women's trafficking in Nigeria. It will explore the gender dimensions of poverty to unravel the extent to which poverty as a factor actually drives this incidence. It investigates the assumptions of the centrality of women's role in increased incidence of human trafficking in Nigeria using some media reported cases of women and trafficking. Using the Capability Framework propounded by Amartya Sen and Martha Nussbaumn, the paper examines how gender inequalities and the failure of the State to guarantee women's human rights weakens women's lack of capabilities and potentials for seeking societal considered respectable means of employment and thereby increasing opportunities for women's involvement in human trafficking..
\end{abstract}

Keywords : Women, Poverty, Trafficking, Human rights.

\section{INTRODUCTION}

The parameters of this articles allows for definitions of the major concepts around which discussions on the subject matter - Poverty and human trafficking.

\subsection{Poverty -Conceptual Definitions}

Poverty has been systematically linked to human trafficking especially in Sub Saharan Africa. The concept of poverty has been widely explored to determine its dimensional thrust and its implications on both individuals and the cooperate society at large. Prior to

* The material presented by the author does not necessarily portray the viewpoint of the editors and the management of the Institute of Business \& Technology (BIZTEK) or Covenant University Ota, Ogun State Nigeria.

*Fayomi O. O : olu_fayomi@yahoo.com

(c) JMSS is published by the Institute of Business and Technology (BIZTEK). Main Ibrahim Hydri Road, Korangi Creek, Karachi-75190, Pakistan. 
the expansion of the concept of poverty, the World Bank measure of poverty on the basis of income and purchasing power provided a foundation for measuring poverty in the area of socio-economic analysis. This income poverty measure loses credibility in the face of the multi-facets and social dimensions of poverty that has for some time become the center of empirical studies on economics and social analysis and livelihoods. Chambers (1995) provides a wide spectrum of the multi-dimensionality of poverty and how it can encompasses a wide spectrum of deprivation and disadvantage which include the absence of dignity and self respect through isolation, physical weakness, and seasonal vulnerability to shock, stress and lack of means to cope with loss. Also, the limited ability of to take cognizance of the significance of non-monetary resources employed by the poor in response to stress is a major weakness of the income poverty measure. Such resources are identified as clan and kinship, support networks, civil society organizations (Elson, 1991, Benerai and Fieldman, 1992)

Furthermore, in an attempt to extend the conceptual clarity of the concept of poverty, following theoretical explorations by seasoned scholars; UNDP progressively in its Human Development Reports (HDR) since the 1990's; and the World Development Report 20002001 by the World Bank have significantly extended the parameters of poverty to encompass security in daily life, empowerment as a human agency; and the ability of people to exercise control over their lives have a political choice. This trend towards a participatory approach to poverty assessments reinforces arguments of the capabilities framework expounded by scholars (Sen Amartya and Nussbuam Martha , 1993, Mahbud ul Haq 1994), which see human development as an end to itself rather than a means to other development goals. Troung (2006) report explains that "central to this framework is the proposition that the absence of entitlements and rights puts a limit on action taken to achieve a meaningful life. They bring to the fore issues of democracy and point to a casual link between a lack of openings for people's capabilities - resulting from an unjust social system - and the prevalence of poverty among particular social groups. He argues further that "placing measures of human development in a matrix representing issues of governance, the capabilities approach allows for a quantification of poverty conditions of special groups. It also gives more credence to the rules of entitlements and that affect women, children and the elderly and any marginalized ethnic groups".

Whitehead and Lockwood (1999) also argue that the money metric poverty lines has profound implications for analyzing gender issues because of its heavy dependence on household survey data. For them, "measuring poverty based on household expenditure survey data is open to long-standing criticism about distribution" because per capita or adult equivalent measures effectively makes assumptions about equal intra-household distribution of resources". Similar to their opinion, Sen (1990) argues against the assumptions that the house hold is a joint utility function. He insists that the conjugal unit of the household is a site of cooperative/conflict. Reinforcing these views, a World Bank report Uganda shows an awareness of the problems arising from the limitations of using aggregated data in poverty assessment of countries. It states that "the importance of examining intra-household resource allocation cannot be over-emphasized. The resource allocation processes within households reflects the status, bargaining power and options of the parties concerned, which in turn are largely a function of control over assets and income. However, women generally do not, and are not expected to control cash income or economic assets; they remain in the subsistence sector, where their economic contribution is not valued but taken for granted. Household expenditure patterns, as revealed in the Household Budget Survey, confirm that gender inequity within the household is an extremely important dimension of Poverty' (World Bank, 1999: 33).

\section{GENDER AND POVERTY}

Studies have in one way or the other sought to link poverty with the incidence of human trafficking especially for sex trade. They argue that the level and persistence of poverty 
in the sub-Saharan Africa aggravates the incidence of human trafficking among lowincome countries. Central to the preservation of this argument is the concept of the feminization of poverty. This conception provides that women are the majority percentage of the world's poor. Women provide over 75 percent of the world's labour and yet have less than 10 percent control over world resources and assets, CIDA (1999) In Nigeria, where 70 percent of the population is reported to be living below income poverty line of $\$ 1$ per day; women make up greater percentage of the poor in Nigeria. Gender inequalities in the social, economic, and political spheres of development further marginalize women and reinforces their disadvantaged position in the society especially in the access to and control over resources, lack of decision making power at family, community and national levels, invisibility of women's economic contributions to the growth of the society as a result of the non-recognition of women's labour in the national accounting processes. Although women make up half of the population, their formal representation in governance institutions is very limited. At the ministerial represent a paltry 0.1 percentage, 4.7 percent at the Assembly, 2.8 percent at the Senate 0.6 percent at the local councils. Also, only 60 percent (2003 figures) of school age children attend primary school with significant regional negative gender gaps for girls than boys CIDA (2005).

Gender comparative data for adult literacy reveal a wide gender gap of 74.4 percent for males as against 59.4 percent for females in 2003 figures. In formal employment sector men fare much better than women in Nigeria. Women's employment participation in the industrial sector is $11 \%$ compared to 30 percent for men. Also in the Federal Civil Service, (the largest single employer of labour in Nigeria,) 76 percent of people on the payroll are men compared to 24 percent of women, while less than 14 percent of management level officers are women. In addition, in the medical profession (even with the recent inflow of women into the profession) men still have an upper hand. Gender statistics report that women represent less than 20 percent of workers especially at the highly skilled positions (with the exception of nursing) compared to 80 percent of men (CIDA, 2005). Such gender disparities continue to increase women's proclivity to poverty manifestations in Nigeria.

\subsection{Human trafficking}

Human trafficking as articulated by the UN Protocol to Prevent, Suppress and Punish Trafficking in Persons, Especially Women and Children, UNGASS (2000) is -

"The recruitment, transportation, transfer, harboring or receipt of persons by means of the threat or use of force or other forms of coercion, of abduction of fraud of deception, of the abuse of power or of a position of vulnerability or of the given or receiving of payment of benefit to achieve the consent of a person having control over another person for the purpose of exploitation".

Exploitation shall include at a minimum the exploitation of the prostitution of others or other forms of sexual exploitation, forced labor or services, slavery or practices similar to slavery servitude or the removal of organs Consent of the victim becomes irrelevant within the context of this definition. The Protocol assumes that adults and children of both sexes can become victims of human trafficking. It also postulates that individual free wills of victims must have been manipulated, constrained, subdued in some manner to allow for exploitation.

The process of trafficking in human beings has essentially been divided into three phases namely recruitment, transferal and exploitation in the country of destination. Women and girls are the major social groupings of the population that has been identified both as perpetrators and victims. As a result, they have been seen to play essential roles in the three phases. The extent to which women are involved and the reasons for such involvement are a major thrust of discussions in this article. Human trafficking abounds in the forms 
of trafficking for child labor and prostitution. This article limits itself to the latter form of trafficking since it usually targets women as promoters, perpetrators and victims.

\section{TRENDS IN TRAFFICKING OF WOMEN IN NIGERIA}

Despite the fact that the incidents of trafficking in women and children in Nigeria had been going on as far back as the 60s, the public recognition for the issue came to limelight in the mid 90's; as a result of the publicity generated by massive deportation of trafficked persons for prostitution to Europe and the Middle East, Olateru (2001). Nigeria experiences internal and external trafficking of women and girls. Internal trafficking takes the form of recruitment and transportation of women and adolescent girls from rural areas to the urban city centers for exploitative sex work and prostitution. External trafficking is trafficking of across National borders for like purposes. Such recruitment is predominant with young women and girls from Edo, Delta, Cross Rivers, Akwa Ibom, Benue, and recently has extended to some states in South Eastern Nigeria to include Imo and Abia States. Destination site is mainly Lagos and some major cities in the northern part of the country such as Kaduna and Kano States for internal trafficking. A WOCON report indicates report that "studies also show that in Asewere a village between Ondo and Ore in Ondo State of Nigeria, lorry loads of women and children from the South Eastern States of Nigeria are dumped by traffickers and distributed for various forms of labour including prostitution". With regards to external trafficking, the recruitment of girls for trafficking route to Europe is predominantly from Edo and Delta States. There are also records of recruitments from other States such as Imo, Enugu, Lagos Ogun, Anambra and AkwaIbom (Report of International Criminal Police Organization, 2000). For the Middle East particularly Saudi Arabia, recruitment of girls is predominantly from the Northern part of Nigeria especially, Kano, Kwara and Kaduna States. Thousands of Nigerian women and children have been trafficked to Europe, particularly Italy. According to the Nigerian Ambassador to Italy, a survey indicates that over 10,000 (ten thousand) Nigerians are engaged in prostitution in Italy. This large number is buttressed by the declaration of the then Italian Ambassador to Nigeria that Nigerian girls constitute $60 \%$ of all prostitutes in the sex trade in Italy (News Magazine, Oct. 4, 1999).

The usual bait for luring the Nigerian girls into trafficking for prostitution is a false promise of employment to earn the much-valued foreign exchange, or vocational training or marriage. Those trafficked to Saudi Arabia usually use the bait to perform the holy pilgrimage to Mecca an Islamic injunction and an opportunity for importation of high profit items Olateru (2001). Commitments from victims are ensured by coercing and forcing such individuals into ritual oath taking using blood, finger nails, and other private body parts performed by a Juju priest. Reprisals for renegade victims range from madness to death. Such oat taking is effective in instilling fear into victims and ensuring their allegiance and commitment to the "contract of agreement" obtained from such process. To further perfect the transaction, the traffickers or their Agents engage the services of lawyers to draw up tripartite agreement referred to as "Friendly agreement".

The routes to the various destinations are dynamic and are as varied as the different syndicated gangs of traffickers. Some of the commonest routes are by land from Nigeria through the neighbouring countries of Republics of Benin and Togo to Ghana or Mali where orientation and change of identities are conducted for those to travel by air. Another route is through North African countries like Morocco or Libya and through the Suez Canal to Spain or Britain and other parts of Europe. In recent times there has been an increase in young girls claiming asylum in Britain but who a re however lured into trafficking for prostitution in Europe (Daily Telegraph, Mar. 2000). On arrival at destination in Europe or Middle-East the trafficked young women get their personal belongings, including travel documents confiscated and are forced into prostitution and repayment bonds of amounts raging between $\$ 30000-\$ 50000$ U.S. Dollars (Women's Consortium of Nigeria (WOCON) Advocacy Report). 


\begin{abstract}
"Every year, thousands of Nigerian women are trafficked into Western Europe and forced to work in the sex industry to pay back debts of up to US \$50,000. Having entered Europe illegally, the women are pushed onto the periphery of society. Ninety-five percent of the women who are trafficked from Nigerian come from Edo State in the south where traffickers have set up their networks. The madams control the women through the practice of juju (voodoo), which is carried out before they .are trafficked out of Nigeria. Juju is a strong spiritual tradition in Southern Nigeria, based on the unbreakable bedrock of faith, and the psychological fear is very recall for these women. During a juju ceremony, an oath of loyalty is signed between a god, the trafficker and the woman. The god keeps the woman's spirit until the debt is paid".
\end{abstract}

Excerpt from Broken Bodies; Broken Dreams: Violence against Women Exposed published by OCHA/IRIN 2005

\title{
4. THE LINKAGES IN WOMEN, POVERTY AND TRAFFICKING
}

In order to properly understand the linkages between trafficking, poverty and women; it is important to examine identified causes of human trafficking. Trafficking can be sociocultural, economical, and politically induced especially according to and within the context of incidence. $T$ he three levels identified would apply to the Nigeria especially with special regards to the individual contexts in which trafficking takes place.

\subsection{Social and Cultural Factors}

The patriarchal nature of the Nigerian society dictated by social systems and practices enables the gravitation of women and girls to gravitate towards human trafficking both as perpetrators and victims. Systemic discrimination, subordination and invisibility of women promoted by cultural norms and practices which characterize gender relations at the household, family levels and perpetuate the perception of women as inferior. This perception increases gender inequalities, which in turn exacerbates the burden of poverty for women. As a result, even though women make up half the population and also make indispensable contributions through to development and growth of the Nigerian economy direct economic productive labour and social reproduction; endemic institutionalized discrimination ensure that, women lack access to and control of resources; occupy an irrelevant minuscule percentage of decision making power; and remain vulnerable to numerous sexually transmitted diseases including HIV / AIDS.

\subsection{Property and Inheritance Rights}

As with all heavily patriarchal societies, the expectations of men and women differ with regards to already compartmentalized roles and behaviour expectations. Women and men rarely enjoy the same opportunities or privileges due to discriminating attitudes and treatment differentiation. Men have much greater control over resources and decision making than women in Nigeria. Women have less say in decision making and are less able to act as subjects to issues of land or property ownership. Onibokun and Faniran (1995) state that although there is little or no data on women's role in relation to land ownership and farming but statistics on land registration show that 90 percent of all land in the country is registered in men's names.

Customary laws in Nigeria further marginalize women. Every Nigerian citizen has a constitutional right to own property; Moreso, the statutory "Married Women's Property Act" allows a woman rights to own and dispose of land and property and to a share of her husband's property on death or divorce; on the condition that she produces documentary 
evidence of her contribution throughout the marriage. The "contribution' as referred to here is commonly taken to be financial contribution which negates the woman's contribution to social reproduction and the production of health within the household. . Even in the cases, where women are engaged in remunerative labour and can afford to make significant economic contributions to the household; social relations and role expectations at the household level among women and men makes it very difficult for some women to be able to acquire and keep documental evidence of such contributions. While such actions might be termed divisive by the male conjugal head and the extended family actors (who actually might argue that the woman is already planning for the divorce or separation), for most women such acts are subsumed within the wider concept of altruism and they might never consider it important enough to keep such evidences.

The non-monetarized daily maintenance activities by women that of persons and institutions that make production possible is by and large never accounted for in the calculus of growth and redistribution in Nigeria, ,Troung (2006). The non-inclusion of the women's contribution towards social reproduction in the calculation of the Gross Domestic Product (GDP), devalues women's work and increases their invisibility.

In addition, most customary laws do not allow for women inheritance especially among the Igbos of South East Nigeria. However, among the Yoruba's, daughter have a share to the father's property or land. Islamic laws allows for a woman to inherit her husband's property except on divorce. These cultural practices reduces their women's for economic autonomy and in the longer terms their inability to operationalize their agency; increased their vulnerability to poverty, disease and death.

\subsection{Sexual and Reproductive Rights}

Also cultural norms and practices affect negatively the ability of women and girls in Nigerian to implement sexual and reproductive rights. Men's desire to control women's bodies is a major issue of sexuality that most often or not ends in the proliferation of violence against women. Women's bodies have become sites of sexual conquest for men and an indication of virile masculinity and control. Similar to practices in other parts of Africa, the Nigerian culture allows for men's sexual urges as natural and part of the normal scheme of things in the society, whereas women's sexuality is viewed as an aberration, colored with much guilt and shame. In Nigeria, the beating of women is culturally sanctioned and ignored by law-enforcers, Hodges (2001). These aspects of culture perpetuate women's invisibility, voicelessness and powerlessness to activate their agency and be more proactive in participating and benefiting in development.

\subsection{Economic Factors}

Poverty is directly linked to be a major cause of trafficking for both women perpetrators and victims. The quest for survival as a result of prevailing inequitable allocation of resources and unemployment are considered major motivators for indulgence in human trafficking. With the current high rate of unemployment among graduate youth, gendered nature of access to and allocation of productive resources, restricted mobility for women in the formal labour force (women represent a greater majority in the informal and unskilled labour) due to lack of appropriate capacity; lack of access to appropriate degree of education etc. women represent a greater percentage of unskilled unemployable and cheap labour. The dire need to meet economic demands and escape poverty drives women and girls and may drive then to seek solace in trafficking especially in the area of sex work and prostitution. In this case, Trafficking becomes an alternative poverty alleviation strategy for survival. A more indent discussion of this issue is undertaken later in this paper. 


\section{WOMEN: VICTIMS OR PERPETRATORS?}

Since 1994 there has been an increase in the massive deportation victims of trafficking for prostitution. According to unofficial Police report, over 1000 Nigerian women and girls have been deported from Europe between January and April 2001 and over 2000 from Saudi Arabia, Olateru (2001). Trafficking in human beings has detrimental consequences to the society and individual. It affects victim's legal, social and financial situation. It also has major undesirable health consequence, which could be both physical and psychological. From the pre-departure stage, to the travel, transit and destination stages, through to detention, deportation, and integration or return and reintegration, women and girls experience repeated physical, sexual and psychological abuse or torture including forced or coerced use of drugs and alcohol, lack of adequate food, withholding of medical treatment, forced protected sex, threats or intimidation of their loved ones, denial of privacy, frequent relocation, public discrimination and social exclusion Zimmerman (2003).

Trafficking is detrimental to health of the victims in several ways. A report by Sofo (2003), states that victims are usually subjected to "cruel mental and physical abuse, designed to break down initial resistance, including confinement, seclusion, threats, humiliation, beatings and sexual abuse. This treatment places the victim under severe stress, often leading to trauma and depression. The risk of contracting sexually transmitted diseases is very great. This is especially because trafficked women and girls are not able to negotiate safer sex; they are also highly vulnerable to contracting sexually transmitted infections. Although, statistics are not readily available for the Nigerian situation; in countries such as Nepal, Cambodia and Zambia prevalence is put at 20 percent, 29 percent and 70 percent are infected with HIV, respectively (UN Special Rapporteur on VAW, 2005).

The Report of the UN Special Rapporteur also indicates that physical injuries are also common. Unwanted pregnancies among women and girls who are sexually exploited not infrequently lead to dangerous abortions. The physical, mental and social development of women and girls is severely impaired and the victims are usually marked for life by the treatment and experience they undergo. Furthermore, the report records that victims suffer social exclusion which include rejection by families and communities, difficulty in starting families of their own and employment; and they may be further subjected to other forms of exploitation. This is especially so in Nigeria, where women and girls appears to represent a greater percentage of trafficked persons. The chasm between men and women's status is persistently widened as women's bodies are commoditized and perceived as the site for sexual exploitation either for free or paid pleasure. Little is known of the economic and social conditions of the sponsors are rife as to their high degree of economic comfort they enjoy as a result of financial dividends that are said to accrue to them incrementally during this period.

On the other hand, damages to the mental, psychological and physical health of trafficked victims especially, at the stages of active sexual exploitation at destination sites, repatriation and reintegration. Media reports have shown a high degree of ostracization and rejection of these victims by families and large societies; and also increases infection of HIV/AIDS.

\section{CASE STUDIES: REVIEW AND ANALYSIS}

Researchers have described a convergence of push and pull factors for the supply and demand side of human trafficking. On the supply side, push factors identified for women and girls with the private domain include domestic violence, child sexual abuse, single parenthood or inducement by impoverished parents or criminal husbands Zimmerman (2003) US Dept of State (2005). While lack of education and employment opportunities and poverty, and HN / AIDS are identified as push factors within the broader societal level. Pull factors include the desire for a higher standard of living, increased migratory flows and the timing and apparent quality of the offer to depart Zimmerman (2003). 
Also, on the demand side, researches have shown a number or push and pull factors in the Asian continent for women and girls. In countries such as India, Pakistan, Burma, Nepal and Thailand, girls may be sold into prostitution to payoff money loaned to their parents UNICEF (2001). In spite of the factors of poverty, greed, organized crime and commercial profit, the sex industry throughout the world is also identified as the primary motivator on the demand side. Also age of the trafficked woman or girl could serve as indicator of her powerlessness and vulnerability. Studies have shown a preference among men for young female prostitutes of 18 year or below because of the desire of these men to protect themselves from HIV / AIDS or the desire to acquire a cure for HIV positive male clients.

Within Africa, Nigerian is by far the largest single source for trafficking No one knows exactly how many women leave for Europe each year, but well over 500 Nigerian girls were deported back from Italy alone last year. According to media report, 80 per cent of the girls who are trafficked from Nigeria are thought to come from two states, Edo and Delta. Women have been seen as major players especially in human trafficking for sex work with and outside the boundaries of Nigeria. Aside from the fact that women and girls are the majority victims for sex trade; it has been severely argued that women are the central motivators, negotiators, recruiters, sponsors and also employers of trafficked women and girls at the end of the supply chain. The supposedly very little participation of men presupposes that women are the major stakeholders and primary beneficiaries of the accrued wealth from the sex trade business in Nigeria and beyond. Some of the case studies below will enable a better appreciation of the role women play in sex trafficking for the sex trade in Nigeria and the extent to which poverty is linked as a pull or push factor.

\subsection{Case 1}

My 22 year old niece, Beatrice, was a victim of this problem," says Joe I (last name withheld), "she lived in a very nice house in the GRA (Government Reservation Area) in Benin, Nigeria. Everyday she was crying. She had heard that this person was building five houses. She kept asking herself what I can do right now to meet up with the Joneses. One day she disappeared." Out of the blues Joe says he was informed that his niece was in Holland. His niece was a slave - a sex slave. According to Joe, his niece had met up with a 'madam' in Benin. The madam promised her that she would be able to transport her to Europe. In return, the madam made Joe's niece swear before juju (charm) that she would not run away before she repaid the 'madam' her $\$ 25,000$ costs for transportation and initial upkeep in Europe. Beatrice arrived Amsterdam after a 6-hour flight from Lagos. Her sponsor had facilitated her Nigerian passport and a visa necessary for entry into Holland. Her first night in Holland was unforgettable. She was driven straight to Amsterdam's red light district and shoved into a dormitory like living quarters that housed 30 other young women. The girls in there were as young as 15 . That night she was introduced to John. John was the enforcer, the pimp. He gave her a quick understanding of what was expected of her. Once she had repaid the $\$ 25,000$ she was free to go. Her living expenses would be on top of that amount. That night Beatrice began her activities as a prostitute. Joe rushed to Europe to try to get his niece back. Despite his pleading with his niece, nothing could get Beatrice to leave Amsterdam. She was afraid of the juju oath she had undertaken in Benin. Not having the $\$ 25,000$ necessary to free Beatrice, Joe returned to America dejected. (Culled from the Internet, an article by Tessa Crawford, 2006)

\subsection{Case 2}

An eighteen year old girl by name Oghogho was recently arrested at the Muhammed International Airport by the Nigerian Immigration Service en route to Italy. Oghogho, who is an SS3 student, claimed that a family friend "Lady G" procured the international passport and the resident identity card that was found on her. She said that Lady G promised to take her to Italy to join her aunty, Evelyn, who is based in Italy. The victim claimed she was told to come to Italy to take care of her aunty's children and that she was a victim of a broken home, her mother having re-married and lived in Lagos while her father is based 
in Benin City. She suffered deprivation because of the broken home that spiritual nature of man to the supernatural being or as involving a feeling of dependence and responsibility, together with the feelings, practices which naturally flows from such a belief. Another issue raised alluded to religion a social phenomenon binding man to man and man to his creator or some ideals. Religion, participants summarily agreed could be defined as the expression of a fundamental faith or belief that manifests in his relationship between a supreme being, spirit or ideals on one hand and his fellow human beings.

\subsubsection{Aspects of Religion:}

Flowing from the above, it would suffice un-bundle the different aspects of religion for the purpose of gaining a deeper understanding into the whole concept of religion and as a guide into gaining a structured and interpretative understanding of the effects of religion on society as well as the organization and management of society. Three core aspects of religion are identified. These are the spiritual, moral and humanistic aspects of religion.

\subsubsection{Spiritual:}

It is probably necessary and very important to discountenance the suggestion that religion is a supernatural relationship between man and God only. Doing so would be denying the larger aspect of spiritual content of religion and buttressing the whole idea of the "noble lie" as espoused by Plato's "Religion - the Noble lie". It is therefore important to state that the contextual categorization of the spiritual was why she agreed to travel to Italy. She lamented that she lost the opportunity to sit for her West African Examination Council (WASC) because she wanted to travel to Italy.

\subsection{Case 3}

Also, one Mrs. Oginni from Osun State Nigeria was intercepted by the Nigerian Immigration Service at Dankama control post in Katsina State which she was escorting three young girls across the border to Niger Republic.. She was said to have pretended as if she was going to visit her sister in that country. In the course of investigations, four identity cards showing that the three girls were working with a Hairdressing Salon located in Sabon Gari Kano, were discovered. Oginni's identify card described her as a trader at 3 Brigade, Mammy market Kano. On further search, a letter emanating from the parents of a victim of human trafficking, Evelyn, resident in Libya was also found. In the letter the parents of Evelyn, in Benin City, tongue lashed their daughter for her failure or inability to pay back money to a procurer, one Madam Halima Mohammed, being the money agreed on before she was trafficked to Libya. According to the letter, Evelyn's parents reminded her that her failure to pay back the money would result in their death to be caused by the Aiyelala Shrine, which she sworn to before she traveled. She was ordered in the letter to send the money to Nigeria to pay for the services provided by a native doctor and a woman that prayed in the church to make her travel possible. Her parents were also bitter that she was living with a man, whom she claimed to be her husband. They reminded her that her purpose of traveling to Libya was not to marry but to make money.

From the foregoing analyses, it quite clear as has always been argued that women play the chief roles as recruiters and sponsors of trafficked women in Nigeria and may in some instances be employers of labour in the foreign countries where victims are trafficked. However, it is not enough to assume that trafficking for sex is women's business. It is suffice to say that it appears to be pre-dominated by women at the present. The important question to ask at this point is why is this so? Why does women predominate the trade? Is it as a result of their woman ness, greed or desire to acquire wealth? What is the primary motivator for women to enter into this business? Why do they need to do this?

A simple analysis of the case studies presented tends to the point to desire of women to make wealth especially victims (case 1). This might be a response to societal adulation 
for materialism. Corruption in Nigeria has elevated materialism and the desire to acquire wealth to a degree that the young and the not so young have imbibed the notion of the pursuit of wealth by any means to acquire importance. However, the push and pull factor for prostitution especially for young Oghoho is clearly a factor of deprivation and poverty. The allure of the prospect of earning foreign currency which will provide her with opportunities of improving her life would have been the greatest appeal. The fact that she had jettisoned the prospects of writing her West Africa Examination Council Exams showed to the extent that she was prepared to go to overcome poverty. Case 3 is also buttressed the role-played by "the Madams" to recruit and sponsor trafficked victims. However, an important dimension her is the reported support and encouragement of parents in this trade. In the story, Evelyn became a target for parental aggression and fury for not fulfilling expectation of her parents of making money for them and her sponsor. The criminal compliance of parents is an issue that abets the trafficking trade especially for under aged girls.

Having established the direct linkages between women, poverty and trafficking, a critical gender analysis of women's role in trafficking will reveal that discriminatory social, cultural and political systems that marginalize and subordinate women is at the very foundation of motivating women to populate this business of trafficking for sex. One would argue ordinarily that cultural and moral attributes of virtue in addition to the gender roles of femininness would expectantly act as stop guards to the promoting the alien culture of prostitution. It appears however, that the patriarchal forces of dominion and control and the desire for women to assert control to individuality and visibility are the dual competing factors that have led women to employ the weapon of trafficking for sex as a way of gaining societal importance and visibility.

Sen et al (1993), capability framework places the ability to achieve human development as the central goal and objective of development. The inability to achieve human development is by implication a cause and consequence of Poverty. Also, the capability theory goes further to suggest linkages between the lack of capabilities among disadvantaged social groups and their vulnerability to poverty. In the case of women, trafficking and poverty, various hypothetical postulations come to mind around the issues of capability. Some of these burning questions include the following - (a) Is it the inadequate development of the capabilities of women as a social group that increases their vulnerability to poverty and thus places then in a position to take to human trafficking as form of ensuring access to economic empowerment?- (b)Or could it also be as a result of the inability of the state to ensure accountability to removing discriminatory factors that marginalize women with political, social and economic institutions and structures? (c) Or could it also be explained that women by nature are more prone to be materialistically inclined that they are more inclined to take advantage of any opportunity to increase their wealth status.

Whitehead and Lockwood (1999) contrast approaches that treat poverty statically, as an analysis of categories and characteristics, with those adopting a dynamic analysis of poverty, seeing it as the relational processes of impoverishment or accumulation. They contend that the link between gender and poverty lies at the level of process, and social and economic relations. For this link to be established, they suggest that poverty must be analyzed as relation and process, as must gender. Also in their conclusion, they argues that it is impossible to integrate gender into an understanding of poverty unless the reading of evidence, analysis and policy are all based on these relational processes of impoverishment or accumulation.

Capability arguments of Sen et al and the relational process of impoverishment of women is at the very heart of motivation for women to take to the business of trafficking in women despite the natural femininess, cultural morality, and maternal inclinations of the Nigerian women which are supposed to ensure that trafficking and sex trade remain in the realm of the abominable. The inability to achieve maximum capabilities potentials of women is a function of the deprivation that the average Nigerian women face in everyday life. Such 
discriminatory practices embedded in cultures, norms, practices, amplified through socialization and magnified in institutional structures, cultural, social and political systems ensure that women remain invisible, subordinate, inconsequential and unimportant as individuals in their own right. Importance and status may be achieved and entitlements guaranteed, and acceptance gained by fulfilling or undergoing processes societal approved processes for ensuring such importance for women - Marriage and Childbearing. However, most often such processes does not guarantee se If importance and might fail to act as a protectionist measure against some negative culture and practices that discriminate against women and violate their human rights.

Women in Nigeria have unequal access to economic opportunities - education, jobs, healthcare in additions to lack of access and control over productive resources such as land, labour, technology and capital. Despite the deprivation, women bear the burden of financial responsibility and provisioning and the production of health within households. With women's lower status, less opportunity for social advancement, little access to political power, and a symbolical culturally promoted dependent on men; women are more vulnerable to physical and sexual abuse.

Also the increasing inflation and economic down turn in Nigerian, (though radicalizing and challenging traditional gender roles on one hand, also places an extra burden on women to meet the expectations of economic contributor to the upkeep of the household. While this is accepted generally by men as a necessary action for survival of the family, most men in Nigeria would resist equating this important economic function of the woman to her right to assert some level of control on decision making in the house. Therefore, her income is always regarded as supplementary even when it provides major sustainance for the family. However, the point to make is the double invisible burden that the women bears due to the hypocritical stance of a culture that insists on trivalising her individuality and her economic contribution while also acknowledging (albeit grudgingly) of the necessity of such contribution. Moser makes reference to women's increasing roles in her triple role concept within her framework for gender analysis. She identifies these as reproductive, productive and community work, March et aI, (1999). These roles are typical burdens that the Nigerian woman bears everyday of her life. It is the attempt to meet these demands, and assert her importance more visibility that makes women more to resort to prostitution or human trafficking.

Going by the case studies considered in this paper and other stories of trafficking that has been aired by the media, the centrality of women's role in promoting, abetting and actively participation in human trafficking cannot be denied. However, the predominance of women in the sex trade and trafficking is a response to the systemic discrimination against women in Nigeria and a strategy of overcoming poverty and deprivation aggravated by persisting gender inequalities in every sphere of human and societal development sphere in Nigeria. It is therefore a coping mechanism for not only to meet primary needs of housing, feeding etc but also a mechanism for meeting the strategic need of actualizing and activating their agency. Kofi Anan in a message to the first Pan-African Conference on Human Trafficking held recently in Abuja, Nigeria, presented by Mbaya Kankwenda, the United Nations resident coordinator in Nigeria; called for a continental initiative to end trafficking of women and children in Africa. He recognized that

"Disparities in wealth had widened not only between nations but also between sexes, resulting in the feminization of poverty. Only when (the victims of trafficking) have control over their own lives will this evil trade be brought to an end".

Similarly, Radhika Coomaraswamy, the United Nations Special Rapporteur on Violence Against women explains the predominance of women as victims of human trafficking in the following manner: 
"The lack of rights afforded to women serves as the primary causative factor at the root of both women's migrations and trafficking in women. The failure of existing economic, political and social structures to provide equal and just opportunities for women to work has contributed to the feminization of poverty, which in turn has led to the feminization of migration, as women leave their homes in search of viable economic options. Further, political instability, militarism, civil unrest, internal armed conflict and natural disasters also exacerbate women's vulnerabilities and may result in increase in trafficking".

It is therefore clear the failure of the state to guarantee the rights of women by ensuring a life free from violence and discrimination promotes gender inequities, which also reinforces and magnifies poverty, powerlessness and vulnerability of the Nigerian women. The inability of the state to provide security of lives and livelihoods, assure gainfully employment; foster women effective integration and participation in decision making and public life; initiate and operationalize key processes that will work to guarantee standard quality $0 \mathrm{f}$ life for its citizens especially marginalized social groups such as women and youth makes it possible for these groups to seek other less desirable means of coping with harsh realities of survival.

\section{AGENDA FOR ACTION}

Nigeria has ratified and acceded to various instruments that promote women's human rights and advancement on the global and regional levels. It has also gone ahead to develop national frameworks and institutions in the guise of national policy for women, national policy on health, the national reproductive policy, etc. However, the implementation and down-streaming of these instruments to begin to affect the practical and everyday lives of women and girls is very slow. As a result systemic discrimination still persists in economic, social and political spheres of life. Accountability to achieving the $30 \%$ representation of women in decision making, reducing vulnerability of women to HIV/AIDs, reducing violence against women ( $\mathrm{V} \mathrm{A} \mathrm{W}$ ) especially in the private sphere, advancing women's potentials to participate effectively in the development mainstream in Nigeria is still a dream.

Current efforts to counteract women's trafficking in Nigeria can be divided into three forms: prevention, law enforcement and prosecution of traffickers and protection of trafficked persons which takes place in the form of rehabilitation post repatriation. These efforts are handicapped by issues of corruption to evade punishments, weak legal provisions and social institutions, failure of the Nigerian state to ensure economic security via the implementation of human centered policies, and a culture that exalts of patriarchal paternalism and material acquisition.

\section{MEASURES}

The lack of adequate legislation, proper functioning machinery and an effective judiciary promote the perpetuation of the incidence of trafficking in women in Nigeria. There is need to enforce with purpose legal provisions to being perpetrators to justice. However, government is increasingly making efforts to prosecute traffickers and facilitate their reintegration. Several people have been arrested in recent days in connection with trafficking rings. Also efforts of campaigners such as W omen's Consortium of Nigeria (WOCON), Women Trafficking \& Child Labour Eradication Foundation (WOTCLEF) and the Catholic Church in Nigeria are beginning to payoff. Human trafficking is starting to attract some stigma especially among perpetrators but government need to implement more stringent punitive measures to act as deterrent to prospective traffickers.

There is need to initiate enforceable legislation and processes that will in truth transforms 
gender relations. This could be done at two levels - legislations and mainstreaming gender into economic reform frameworks at national, state and local levels. The opportunity of the National Economic Empowerment Development Strategy (NEEDS), State Economic Empowerment Development Strategy provides an amply opportunity for this, especially as the government of Nigeria has committed itself improving the capacity and potentials of women to participate in development; improving women's participation in decision making to reflect the 30 percent affirmative action in the Beijing Platform of Action; reducing vulnerability of women to HIV/AIDS within the implementation of this economic development framework. International and national agencies are supporting the implementation of the economic framework to ensure gender equality outcomes. Government of Nigeria should take advantage of the monumental interest of the donor community and NGOs in Nigeria to actualize its commitments to achieving gender equality objectives.

It is true that democratic governance in Nigeria has reduced the incidence of violations of human rights, however, violations of human rights especially women's rights continue unabated. The Federal Government of Nigeria lags behind in its commitment of ensuring the implementation of women' and girls' rights with its slow progress towards the domestication of the Convention of the Elimination of All Forms of Discrimination Against Women (CEDA W) and the Convention on the Rights of the Child (CRC), it's non implementation of the affirmative action of 30 percent representation of women at all levels in Decision making and its inability to enact and implement legislations that will eliminate violence against women and foster gender equality between women and men in Nigeria speaks volume of its level of accountability in this regard. It is important that Nigeria begin to take practical steps to actualize the implementation of CEDAW and CRC.

It should prosecute with more zeal the prosecution of the culprits. For instance the government of Nigeria, through the Economic financial Crime Commission has effectively curbed the incidence of advanced fee fraud. The office of Immigration and security officials charged with the primary responsibility of prosecuting perpetrators is in dire need of specialized trained staff with capacity to deal with effectively with this issue. It is imperative that the government of Nigeria prioritizes capacity building for these sectors. The issue of criminal compliance of parents should be properly addressed to attract deserved punishment as by their action they are contravening the Convention on the Rights of the Child.

\section{CONCLUSION}

This paper argues that the issue of violation and non-implementation of women's rights to the feminization of poverty that forms the basis for women's active involvement in human trafficking especially with regards to sex trade. It is indeed true that women play major roles as recruiters, facilitators and sponsors in the trafficking chain in Nigeria. However, the arguments in this paper tried to show that institutionalized and systemic discrimination and marginalization of women is the major factor that promotes the pauperization of women and motivates their involvement in the human trafficking. Furthermore, this paper argues that until the Government of Nigeria translates it commitments on gender equality into practical action to affect the realities of the lives of women in Nigeria, women's involvement in trafficking in Nigeria would be difficult to curb. It is also important that the government builds the capacity of its Nigerian Immigration Service and National Agency for Prohibition of Trafficking in Person and other related matters (NAPTIP) to be able to actively prosecute perpetrators and act positively to protect prospective and repatriated victims of human trafficking.

\section{REFERENCES}

ANUCHA, CHRIS (2006), Immigration Spoils fun of human trafficking, An article published on Crime watch, The Daily Sun, June, Pg. 20. 
BENERIA, LOURDES AND SALLY FELDMAN (EDS) (1992) Unequal Burden: Economic Crisis, Persistent Poverty and Women's Work, Boulder, Co: Westview Press. Canadian International Development Agency (1999) Gender Policy

CHAMBERS, ROBERT (1995) Poverty and Livelihoods: Whose Reality Counts? Environment and Urbanizations 7 (1): 173-204

CIDA (2005), Gender Support Pilot Project: Concept Paper and Abbreviated Management Strategy - Final Version

CRAWFORD TERESA, GIRLS FOR SALE: TRAFFICKING FROM NIGERIA (FWD) accessed at http://groups.google.com/group/soc.culture.nigeria/browse _thread on 24/05/06 Daily Telegraph March 9, 2001.

ELSON, DIANE (1991) Male Bias in Macroeconomics: The Case of Structural Adjustment, in Male Bias in the Development Process, Diane Elso (ed.), Manchester, - Manchester University Press.

HAQ, MAHBUD UI (1995) Reflections on Human Development, New York: Oxford University Press.

HODGES A. (ED) (2001) Children's and Women's Rights in Nigeria: A Wake-up Call, Situation Assessment and Analysis, UNICEF/National Planning Commission, Nigeria Isiramen Celestina Omoso, (2006) Women in Nigeria: Religion, Culture, and AIDS IHN 2003.4 November/International Humanist News accessed on http://www.iheu.org/node/979 on 19105/06

MARCH CANDIDA, SMYTH INES, AND MUKHOPADHYAY, (1999) A Guide to Gender Analysis Frameworks, Oxfam GB.

NEWS MAGAZINE, October 4, 1999 pg. 44.

NIGERIAN DIVISION of International Criminal Police Organization report dated 25th August 2000.

OLATERU BISI, (2001) A Contemporary Form of Slavery; Combating Child Trafficking in West and Central Africa in World of Work, No 39, June 2001

ONIBOKUN A. AND A. FANIRAN (EDS) (1995), Women in Urban Land Development in Africa: Nigeria, Ghana and Tanzania, Centre for African Settlement Studies and Development (CASSAD)

PROTECTION PROJECT, 2004, United States Department of State, 2005.

PROTOCOL TO THE UNITED NATIONS Convention against Transnational Organized Crime, adopted by the UN General Assembly in November, 2000.

SEN AMARTYA (1990), Gender and Cooperative Conflicts Irene Tinker (ed.) Persistent Inequalities: Women and World Development, London: Oxford University Press.

SEN AMARTYA AND NUSSBAUMN MARTHA (EDS.) (1993), The Quality of Life, London: Clarendon Press.

SOFO C.A, AKPAJIKAKI ALI \& PYKE TONI; (2003), Measuring Poverty in Nigeria, Oxfam Working Paper, ISBN No. 085598502x

TRUONG THANH-DAM, (2006), Poverty, Gender and Human Trafficking in Sub-Saharan Africa: Rethinking Best Practices in Migration Management, UESCO Project to Fight Human Trafficking in Africa, France.

UNICEF, (2001), Profiting from Abuse: An Investigation into the Sexual Exploitation of our Children New York.

UNITED NATIONS SPECIAL RAPPORTUER ON Violence against Women, Integration of Human Rights of Women and the Gender Perspective: Intersections of Violence Against Women and HIV/AIDS, United Nations Commission on Human Rights E/CNA/205/72 (Geneva, January 2005).

WHITEHEAD ANN AND LOCKWOOD MATHEW (1999) Gender in the World Bank's Poverty Assessments: Six Case Studies from Sub-Saharan Africa in UNRISD Publication, ISSN: 1012-6511, Geneva.

WOCON AND THE ADVOCACY PROJect - On the Record Girls for Sale - the Scandal of Trafficking from Nigeria: E-mail Series produced by WOCON and the Advocacy Project.

WOCON'S REPORT COPY of Specimen Agreement attached as appendix 2 to WOCON's Report on Research on Trafficking in women in Nigeria commissioned by the Netherlands Embassy, Lagos. 
Women, Poverty and Trafficking: A Contextual Exposition of the Nigerian Situation

WOMEN'S CONSORTIUM OF NIGERIA (WOCON) publication The social and Legal Implications of Trafficking in Nigeria -The modern Slavery.

WORLD BANK, (1993), Uganda - Growing out of Poverty (PA), Washington, D.C.

ZIMMERMAN C, etal. (2003), The Health Risks and Consequences of Trafficking in

Women and Adolescents; Findings from a European Studies, London: School of Hygiene and Tropical Medicine Press. 